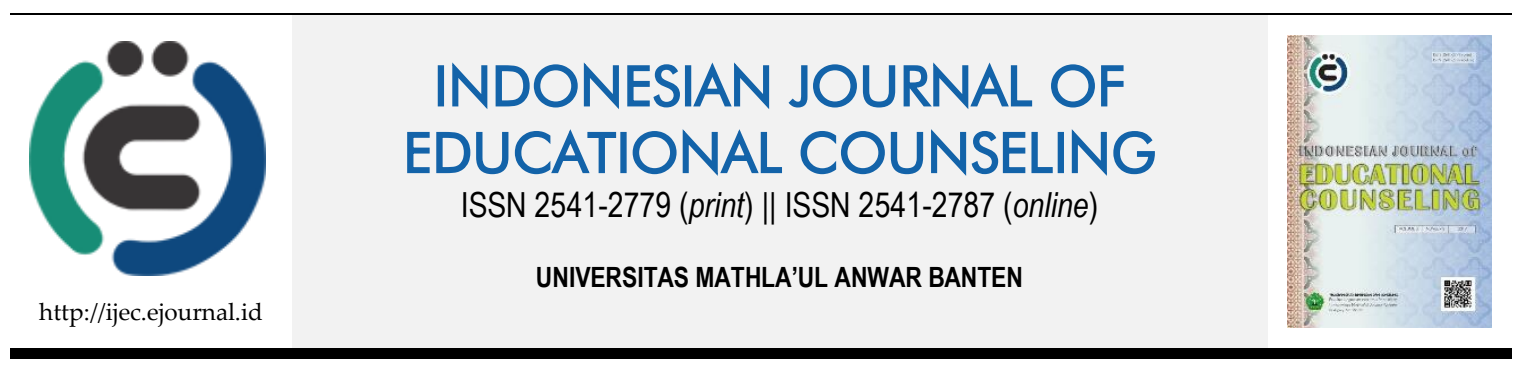

Research Based Article

\title{
Pemanfaatan Media Grafis dalam Layanan Informasi Dampak Pelanggaran Disiplin untuk Meningkatkan Perilaku Disiplin Siswa di Sekolah
}

\author{
Muh. Mansyur Thalib ${ }^{1}$, Ridwan Syahran², Azam Arifyadi ${ }^{3}$ \\ 1, 2,3 Universitas Tadulako
}

\begin{tabular}{ll}
\hline Article History & ABSTRACT \\
\hline Received: 25.03.2019 & UTILIZATION OF GRAPHIC MEDIA IN INFORMATION SERVICES THE IMPACT \\
Received in revised form: & OF DISCIPLINE VIOLATION TO IMPROVE DISCIPLINE BEHAVIOR OF \\
01.04 .2019 & STUDENTS IN SCHOOL. This study aimed to determine the effect of the use of \\
Accepted: 10.04.2019 & visual media in information services on the impact of disciplinary violations on \\
Available online: 05.08.2019 & improving student discipline behavior. This study uses 90 students as subjects (30 \\
& students from SMP Negeri 15 Palu, 30 students from SMP Negeri 3 Palu, 30 students \\
& from SMP Negeri 10 Palu using Pretest-Posttest Control Group design. Research data \\
& collection was conducted using indirect interview techniques as a technique. The \\
& research data were analyzed by descriptive and inferential analysis (t-test). The \\
& results showed that: 1 ) the use of Banner media resulted in 40\% of students increasing \\
& their discipline from low to moderate; 2 ) the use of X-Banner media resulted in 20\% \\
& of students increased discipline from moderate to high, and 23.33\% of students who \\
& increased their discipline from low to moderate; 3) the use of media Leaflets \\
produced 13.33\% of students who increased their discipline from being high, and & \\
& 30\% of students who increased their discipline from low to medium; 4 ) there is an \\
influence on the use of Banner media in information services the impact of \\
disciplinary violations on ked student discipline; 5) there is the influence of the use \\
of X-Banner media in information services on the impact of disciplinary violations \\
on student discipline; and 6) there is an influence of media use Leaflet in information \\
services the impact of disciplinary violations on student discipline.
\end{tabular}

KEYWORDS: Graphic Media, Information Services, The Impact of Indiscipline.

DOI: $10.30653 / 001.201933 .107$

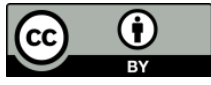

This is an open access article distributed under the terms of the Creative Commons Attribution 4.0 International License, which permits unrestricted use, distribution, and reproduction in any medium, provided the original work is properly cited. ๑ 2019 Muh. Mansyur Thalib, Ridwan Syahran, Azam Arifyadi.

\section{PENDAHULUAN}

Pentingnya perilaku tidak disiplin untuk dientaskan karena memiliki beberapa dampak. Dampak yang dapat muncul dari perilaku tidak disiplin adalah merugikan diri sendiri, merugikan orang lain, dan merusak tatanan dan nilai-nilai pendidikan. Khusus pada diri siswa yang tidak disiplin berdampak pada keterlambatan pada materi pelajaran,

${ }^{1}$ Corresponding author's address: Program Studi Bimbingan dan Konseling, Universitas Tadulako; Jl. Soekarno-Hatta KM.9, Tondo, Mantikulore, Kota Palu, Sulawesi Tengah 94148, Indonesia; Email: mansyur_thalib@yahoo.com 
hubungan sosial menjadi tidak harmonis, masalah kesehatan, masalah moral, fasilitas sekolah rusak dan sebagainya.

Salah satu upaya yang dapat dilakukan untuk menangani masalah kurang disiplin sekolah adalah merancangan materi layanan informasi barbasis masalah di sekolah dan merancang media layanan informasi. Materi berbasis sekolah yang dimaksud adalah mengidentifikasi masalah pelanggara tata tertib di sekolah dan mengidentifikasi dampak yang dapat muncul sebagai akibat pelanggaran tersebut.

Layanan informasi dampak pelanggaran disiplin yang disertai media tersebut akan memberikan informasi/gambaran kepada siswa tentang dampak baik kepada diri dan maupun orang lain yang dapat muncul di kemudian hari akibat dari perilaku pelanggaran disiplin di sekolah. Dari aspek psokologi bahwa jika siswa mencermati informasi tersebut, maka akan muncul kekhawatiran akan dampak pada diri mereka. Jika demikian keadaannya maka siswa akan merubah perilakunya menjadi sesuai dengan norma/aturan (positif). Dengan demikian dapat diasumsikan bahwa upaya tersebut akan memberikan pengaruh positif pada peningkatan perilaku disiplin di sekolah.

Dalam pemberian layanan informasi disertai dengan memanfaatkan media grafis. Ada 3 jenis media grafis yang dilibatkan dalam layanan informasi, yaitu; a) media spanduk/banner ukuran $4 \times 1$ meter, b) media X banner ukuran $6 \times 160 \mathrm{~cm}$, dan c) media Brosur/leafleat ukuran kertas folio. Ketiga jenis media grafis tersebut diterapkan pada tiga sekolah yang berbeda namun semuanya berada pada sekitar kota Palu.

Masalah dalam penelitian adalah a) bagaimana peningkatan perilaku disiplin siswa setelah memanfaatkan media grafis dalam layanan informasi dampak pelanggaran disiplin? dan apakah ada pengaruh pemanfaatan media grafis (Banner, X-Banner, dan Leafleat) dalam layanan informasi dampak pelanggaran disiplin terhadap pengembangan perilaku disiplin siswa?

Badru Zaman (2005) mendefinisikan media "sebagai wahana dari pesan yang oleh sumber pesan (guru) ingin diteruskan kepada penerima pesan (anak)". Nursalin, M (2015) menyatakan bahwa "media bimbingan dan konseling adalah merupakan wadah dari pesan, materi yang disampaiakan adalah pesan bimbingan dan konseling, tujuan yang ingin dicapai ialah perkembangan siswa secara optimal". Sofah, R. Dan Sucipto, S.D. (2016) mengidentifikasi lima manfaat media dalam layanan bimbingan dan konseling, yaitu: “ a) membantu proses layanan bimbingan dan konseling lebih menarik, b) meningkatkan kualitas layanan bimbingan dan konseling c. memperlancar proses bimbingan dan konseling d. sebagai alat bantu untuk mewujudkan situasi bimbingan dan konseling yang efektif, dan e) sebagai alat bantu untuk mencapai tujuan bimbingan dan konseling". Media Grafis yang akan dilibatkan dalam penelitian ini adalah media spanduk, X-Banner, dan Leaflet.

Spanduk, menurut Mulyana (2009) adalah merupakan media luar ruang dan iklan visual yang biasanya digunakan untuk menyampaikan pesan secara ringkas di atas kain yang dibentangkan di tempat-tempat umum yang letaknya strategis". Amrulloh, A.F. (2013) mengdentifikasi beberapa manfaat yaitu: 1) bukan hanya sekedar untuk dipandang saja, spanduk dapat mempengaruhi citra produk suatu perusahaan, lembaga maupun sebuah instansi; 2) spanduk dapat mempengaruhi citra produk suatu perusahaan, 
lembaga maupun sebuah instansi; 3) menimbulkan kepercayaan orang banyak, khususnya konsumen terhadap suatu produk ataupun bisnis; 4) mengingatkan masyarakat umum pada produk atau perusahaan; 5) menimbulkan atau membangun loyalitas masyarakat umum atau konsumen terhadap suatu bisnis. Di sekolah spanduk dapat dijadikan sebagai media informasi kepada siswa-siswa dengan memasang pada tempat yang strategis di sekolah. Dalam penelitian ini media Spanduk dijadikan sebagai alat promosi disiplin kepada siswa-siswa di kelas.

X-Banner, menurut Shimp, A.T. (2003) X-Banner adalah sebuah media yang berfungsi untuk menyampaikan informasi dalam bentuk banner yang dilengkapi dengan kontruksi penyangga berbentuk " $X$ " sehingga banner bisa berdiri sendiri. Media banner ini memiliki bentuk yang ringkas dan dapat diposisikan dimana saja, sehingga efisien apabila dipasang berhadapan dengan siswa di kelas, maupun ditempat-tempat yang sering dijumpai agar siswa dapat melihat dengan mudah isi informasi yang akan disampaikan. Shimp, A.T. (2003) menyatakan bahwa tujuan banner adalah sebagai media iklan, promosi, publikasi, menjalin persahabatan dan berbagai kepentingan lainnya. Dalam penelitian ini media X-Banner dijadikan sebagai alat promosi disiplin kepada siswa-siswa di kelas.

Leaflet dalam bimbingan dan konseling adalah media bentuk grafis dan dapat dilipat, serta berisi informasi dalam bidang pribadi, sosial, belajar, atau karier. Tujuan leafleat bimbingan dan konseling dibuat untuk memberikan informasi yang dibutuhkan peserta didik/konseli (Ditjen GTK Kemendikbud: 2016). Ciri-ciri leafleat menurut Muakhir (2012), jika dilihat dari bentuknya berupa lembaran kertas berukuran kecil yang dicetak, dilipat maupun tidak dilipat, tulisan terdiri dari 200-400 huruf dengan tulisan cetak biasanya juga diselingi gambar-gambar, dan ukuran biasanya $20-30 \mathrm{~cm}$. Jika dilihat dari isi pesannya berupa pesan sebagai informasi yang mengandung peristiwa, bertujuan untuk promosi, dan isi leaflet harus dapat dibaca sekali pandang. Muakhir (2012), mengidentifikasi manfaat leafleat dalam pelayanan layanan bimbingan dan konseling, sebagai berikut: 1) dapat menyampaikan pesan-pesan dan informasi tertentu kepada peserta didik; 2) dapat mempengaruhi dan mengubah tingkah laku peserta didik;3) dapat memberikan motivasi kepada siswa dalam rangka pengembangan dirinya; 4) menghindari rasa jenuh dan bosan terhadap siswa; 5) memberikan pengalaman kreatif kepada siswa agar mampu untuk lebih kreatif lagi dalam belajar.

Menurut Winkel \& Hastuti, S (2015) mengatakan bahwa: "layanan informasi bertujuan untuk membekali para siswa dengan pengtahuan tentang data dan fakta dibidang pendidikan sekolah, bidang pekerjaan, dan bidang perkembangan pribadisosial, supaya mereka belajar tentang lingkungan hidupnya dan mampu mengatur serta merencanakan kehidupannya sendiri. Langkah pelaksanaan pemberian layanan informasi yang dikemukakan oleh Sukardi, D.K \& Nila Kusmawati, D.P.E.N (2008), yaitu: a) langkah persiapan, b) langkah pelaksanaan, c) langkah evaluasi.

Departemen Pendidikan Nasional (2001) menjelaskan bahwa "aspek-aspek yang tercakup dalam tata tertib itu adalah sebagai berikut: 1) tugas dan kewajiban dalam kegiatan sekolah meliputi: a) masuk sekolah, b) waktu belajar, c) waktu istirahat, d) waktu pulang, 2) upacara besar dan hari lainnya, 3) cara berpakaian, 4) larangan-larangan bagi pelajar/siswa, 5) meninggalkan sekolah/pelajaran selama berjam-jam pelajaran berlangsung, tanpa izin kepala sekolah, guru yang bersangkutan dan guru piket". 
Pelanggaran terhadap tata tertib akan memberikan efek negatif yang dapat membuat siswa menjadi malu. Penyadaran dan penanaman budaya malu inilah yang menjadi materi dalam penelitian ini. Materi selengkapnya akan menjadi lampiran laporan ini.

Menurut Siswanto (2003) bahwa "disiplin adalah suatu sikap menghormati dan menghargai suatu peraturan yang berlaku, baik secara tertulis maupun tidak tertulis serta sanggup menjalankannya dan tidak menolak untuk menerima sansi-sanksi apabila dia melanggar tugas dan wewenang yang diberikan kepadanya". Tujuan disiplin sekolah menurut Rimm, Silvia (2003) adalah "(1) membantu anak untuk menjadi matang pribadinya dan mengembangkan dari sifat-sifat ketergantungan sehingga ia mampu berdiri sendiri atas tanggung jawab sendiri, (2) membantu siswa untuk mengatasi, mencegah timbulnya problem-problem disiplin dan berusaha untuk menciptakan situasi yang tertib bagi kegiatan belajar mengajar dimana mereka mentaati segala peraturan yang telah di tetapkan".

\section{METODE}

Rancangan penelitian quasi eksperimen ini menggunakan satu variabel bebas yaitu pemanfaatan media grafis, dan satu variabel terikat yaitu perilaku disiplin. Rancangan penelitian yang dianggap sesuai daakan digunakan adalah Pretest-Posttes Control Group Design yang dapat digambarkan sebagai berikut:

Penelitian ini akan dilaksanakan pada tiga SMP Negeri di Kota Palu. Pada masingmasing sekolah akan diambil sebanyak 30 siswa sebagai subjek penelitian. Oleh sebab itu maka subjek yang menjadi sasaran peneltian ini adalah sebanyak 60 siswa.

Untuk mengumpulkan data penelitian ini maka digunakan teknik observasi dan wawancara tidak langsung, yaitu dengan menugaskan kepada siswa tertentu untuk mengamati subjek penelitian dan selanjutnya dilakukan wawancara hasil pengamatan. Cara ini dilakukan baik sebelum dan sesudah eksperimen. Oleh sebab itu maka instrument yang disediakan hanya pedoman wawancara tidak langsung.

Penelitian ini adalah penelitian kuantitatif, data penelitian dianalisis dengan menggunakan analisis deskriptif dan inferensial. Analisis deskriptif terdiri dari: membuat distribusi frekuensi, menghitung persentase, membuat histogram, dan perhitungan mean. Sedangkan Analisis infrensial (uji hipotesis) dengan menggunakan uji-t sampel tidak bebas, dengan taraf kepercayaan $95 \%$. Sebelum dilakukan uji hipotesis penelitian, maka terlebih dahulu dilakukan uji persyaratan analisis data yaitu: uji normalitas dan uji homogenitas.

\section{HASIL DAN PEMBAHASAN}

Hasil analisis deskriptif tentang perilaku disiplin siswa sebelum dan sesudah diberikan layanan informasi dampak pelanggaran disiplin dengan disertai media Grafis, dapat dilihat pada klasifikasi dan deskripsi perilaku disiplin siswa yang ditunjukkan pada Tabel 1. 
Tabel 1. Peningkatan Klasifikasi Perilaku Disiplin Siswa Sesudah Pemanfaatan Media Grafis dalam Layanan Informasi Dampak Pelanggaran Disiplin

\begin{tabular}{lrrr}
\hline $\begin{array}{c}\text { Media dan Klasifikasi } \\
\text { Perilaku Disiplin Siswa }\end{array}$ & $\begin{array}{c}\text { Sebelum } \\
\text { LIDNPDDMG }\end{array}$ & $\begin{array}{c}\text { Sesudah } \\
\text { LIDNPDDMG }\end{array}$ & $\begin{array}{c}\text { Peningkatan } \\
\text { Jumlah }(\%)\end{array}$ \\
\hline SPANDUK & 0 & 0 & \\
\hline Sangat Tinggi & 0 & 0 & \\
\hline Tinggi & 8 & 20 & $12(40,00)$ \\
\hline Sedang & 22 & 10 & \\
\hline Rendah & 0 & 0 & \\
\hline Sangat Rendah & 30 & 30 & $12(40,00)$ \\
\hline Jumlah & \multicolumn{5}{c}{0} \\
\hline X- BANNER & 0 & 0 & \\
\hline Sangat Tinggi & 0 & 20 & $7(23,33)$ \\
\hline Tinggi & 19 & 4 & \\
\hline Sedang & 11 & 0 & \\
\hline Rendah & 0 & 30 & $13(43.33)$ \\
\hline Sangat Rendah & 30 & & \\
\hline Jumlah & & 0 & \\
\hline BROSUR/LEAFLET & 0 & 24 & $9(13,33)$ \\
\hline Sangat Tinggi & 0 & 2 & \\
\hline Tinggi & 19 & 0 & \\
\hline Sedang & 11 & 30 & $13(43,33)$ \\
\hline Rendah & 0 & & \\
\hline Sangat Rendah & 30 & & \\
\hline Jumlah & & & \\
\hline
\end{tabular}

LIDNPDDMS: Layanan Informasi Dampak Pelanggaran Disiplin Disertai Media Grafis.

Berdasarkan Tabel 1, dapat dilihat bahwa dengan membandingkan klasifikasi disiplin siswa antara sebelum dan sesudah memanfaatkan media grafis dalam layanan informasi dampak pelanggaran disiplin, ternyata terjadi peningkatan perilaku disiplin siswa, yaitu: a) melalui pemanfaatan media Spanduk dalam layanan informasi dampak pelanggaran disiplin, terjadi peningkatan dari rendah menjadi sedang sebanyak 12 atau $40 \%$ siswa, b) melalui pemanfaatan media X-Banner dalam layanan informasi dampak pelanggaran disiplin, terjadi peningkatan sebesar 13 atau $43.33 \%$ yang terdiri dari peningkatan dari rendah menjadi sedang sebanyak 6 atau $20 \%$ siswa dan peningkatan dari sedang menjadi tinggi sebanyak 7 atau 23,33\% siswa, c) melalui pemanfaatan media Leaf-let dalam layanan informasi dampak pelanggaran disiplin, terjadi peningkatan sebesar 13 atau $43.33 \%$ yang terdiri dari rendah menjadi sedang sebanyak 9 atau $30 \%$ siswa dan peningkatan dari sedang menjadi tinggi sebanyak 4 atau 13,33\% siswa. Setelah dilakukan analisis uji-t berdasarkan data disiplin siswa yang terkumpul, maka diperoleh hasil sebagaimana Tabel 2. 
Tabel 2. Hasil Uji-t dari 3 Jenis Media Grafis

\begin{tabular}{lcclcc}
\hline Media Grafis & $\bar{x} 1$ & $\bar{x} 2$ & Selisih & t-hitung & Sig. \\
\hline Spanduk & 177,6 & 185,73 & 18,3 & 5,42 & .001 \\
\hline X Banner & 181,9 & 195,3 & 13,4 & 10,55 & .001 \\
\hline Leafleat & 185,87 & 201,4 & 15,52 & 5,92 & .001 \\
\hline
\end{tabular}

Berdasarkan hasil uji-t pada Tabel 2, dapat diketahui bahwa: 1) hipotesis nol yang pertama berbunyi bahwa rata-rata perilaku disiplin siswa sesudah memanfaatkan media Spanduk dalam layanan informasi dampak pelanggaran disiplin sama (atau lebih rendah) dibandingkan dengan sebelum memanfaatkan media Spanduk dalam layanan informasi dampak pelanggaran disiplin, ternyata ditolak pada taraf signifikasi 0,05. Dengan demikian maka dapat disimpulkan bahwa ada pengaruh pemanfaatan media Spanduk dalam layanan informasi dampak pelanggaran disiplin terhadap disiplin siswa di sekolah. 2) hipotesis nol yang kedua berbunyi bahwa rata-rata perilaku disiplin siswa sesudah memanfaatkan media X-Banner dalam layanan informasi dampak pelanggaran disiplin, sama (atau lebih rendah) dibandingkan dengan sebelum memanfaatkan X-Banner dalam layanan informasi dampak pelanggaran disiplin, ternyata ditolak pada taraf signifikasi 0,05 . Dengan demikian maka dapat disimpulkan bahwa ada pengaruh pemanfaatan media media X-Banner dalam layanan informasi dampak pelanggaran disiplin terhadap disiplin siswa di sekolah. 3) hipotesis nol yang ketiga berbunyi bahwa rata-rata perilaku disiplin siswa sesudah memanfaatkan media Leafleat dalam layanan informasi dampak pelanggaran disiplin sama (atau lebih rendah) dibandingkan dengan sebelum memanfaatkan media Leafleat dalam layanan informasi dampak pelanggaran disiplin, ternyata ditolak pada taraf signifikasi 0,05. Dengan demikian maka dapat disimpulkan bahwa ada pengaruh memanfaatkan media Leafleat dalam layanan informasi dampak pelanggaran disiplin terhadap disiplin siswa di sekolah.

Hasil penelitian pertama menunjukan bahwa perilaku disiplin siswa sebelum memanfaatkan media Spanduk dalam layanan informasi dampak pelanggaran disiplin, ternyata ada 8 siswa yang memiliki perilaku disiplin sedang dan 22 siswa yang memiliki perilaku disiplin rendah. Jumlah tersebut menggambarkan bahwa umumnya siswa ini memiliki perilaku disiplin yang rendah. Setelah memanfaatkan media Spanduk dalam layanan informasi dampak pelanggaran disiplin, terjadi perubahan pada disiplin siswa, yaitu ada 20 siswa yang memiliki perilaku disiplin sedang dan 10 siswa yang memiliki perilaku disiplin rendah. Jumlah tersebut menggambarkan bahwa umumnya siswa ini memiliki perilaku disilpin yang sedang. Dengan demikian ada 12 atau 40\% siswa yang meningkat disiplinnya dari rendah menjadi sedang. Peningkatan tersebut terjadi karena memanfaatkan media Spanduk dalam layanan informasi dampak pelanggaran disiplin siswa, pemberian materi oleh peneliti sangat mudah dipahami, siswa sangat antusias dalam menerima materi, serta media Spanduk yang terpasang di pintu gerbang dan lapangan sekolah sehingga siswa dapat melihat dengan mudah informasi yang disampaikan di dalam kelas. Pada siswa yang tetap pada klasifikasi rendah serta tidak mengalami perubahan klasifikasi karena siswa tersebut saat proses layanan informasi kurang memperhatikan seperti bermain dengan teman, keluar masuk kelas dan kurang antusias dalam menerima materi. 
Hasil penelitian di atas sejalan dengan pendapat Prayitno dan Amti, E.(2011) bahwa "layanan informasi bertujuan untuk membekali individu dengan berbagai pengetahuan dan pemahaman tentang berbagai hal yang berguna untuk mengenal diri, merencanakan dan mengembangkan pola kehidupan sebagai pelajar, anggota keluarga, dan masyarakat". Menurut Winkel \& Hastuti, S. (2015) yaitu "layanan informasi diadakan untuk membekali para siswa dengan pengetahuan tentang data dan fakta di bidang pendidikan sekolah, bidang pekerjaan, dan bidang pengembangan pribadi-sosial, supaya mereka dengan belajar tentang lingkungan kehidupnya sendiri". Ahmad Amrulloh, A.F. (2013) mengdentifikasi manfaat spanduk yaitu: 1) bukan hanya sekedar untuk dipandang saja, spanduk dapat mempengaruhi citra produk suatu perusahaan, lembaga maupun sebuah instansi, 2) spanduk dapat mempengaruhi citra produk suatu perusahaan, lembaga maupun sebuah instansi, 3) menimbulkan kepercayaan orang banyak, khususnya konsumen terhadap suatu produk ataupun bisnis, 4) mengingatkan masyarakat umum pada produk atau perusahaan, 5) menimbulkan atau membangun loyalitas masyarakat umum atau konsumen terhadap suatu bisnis.

Hurlock (dalam Fiana, Daharnis, \& Ridha, 2013) menjelaskan bahwa "disiplin dapat terbentuk dengan cara demokratis yaitu dengan menggunakan penjelasan, diskusi dan penalaran untuk membantu anak mengerti mengapa perilaku tertentu diharapkan, cara ini lebih menekankan pada aspek edukatif dari pada aspek hukumannya".

Hasil identifikasi menunjukkan bahwa disiplin rendah terjadi pada cara berpakaian, perilaku menyontek saat ulangan dan dalam mengerjakan tugas dari guru, serta membuang sampah sembarang tempat. Kondisi ini terjadi terjadi karena cenderung cara berpakaian di sekolah tidak dianggap sebagai hal yang patal dan bukan pelanggaran berat. Begitu juga perilaku menyotek tidak lagi dianggap hal yang patal sehingga terkadang guru tidak memperdulikan pada siswa yang menyontek. Demikian pula masalah pelanggaran dalam mengerjakan tugas, layaknya dianggap biasa saja sehingga siswa juga sudah menggap hal yang biasa saja dan hampir tidak lagi dipermasalahkan di sekolah. Selanjutnya disiplin siswa yang rendah adalah membuang sampah bukan pada tempatnya, juga dinilai bukan masalah yang fatal apalagi hanya dengan sampah kertas atau potong kertas atau pembungkus makanan ringan. Siswa yang memiliki perilaku rendah ini umumnya mereka adalah dari keluarga sederhana dengan pekerjaan orang tua (ayah) adalah kebanyakan wirausahawan dan beberapa lagi bekerja sebagai sopir, PNS, kerja bangunan, bengkel dan sebagainya. Kedatangan ke sekolah umumnya mereka diantar oleh orang tua atau anggota kelurga lainnya.

Hasil penelitian kedua menunjukan bahwa perilaku disiplin siswa sebelum memanfaatkan media X-Banner dalam layanan informasi dampak pelanggaran disiplin, ternyata ada 19 siswa yang memiliki perilaku disiplin sedang dan 11 siswa yang memiliki perilaku disiplin rendah. Jumlah tersebut menggambarkan bahwa umumnya siswa ini memiliki perilaku disiplin yang sedang. Setelah memanfaatkan media X-Banner dalam layanan informasi dampak pelanggaran disiplin, terjadi perubahan pada disiplin siswa, yaitu ada 6 siswa yang memiliki perilaku disiplin tinggi, ada 20 siswa yang memiliki perilaku disiplin sedang dan 4 siswa yang memiliki perilaku disiplin rendah. Jumlah tersebut menggambarkan bahwa umumnya siswa ini memiliki perilaku disilpin yang sedang. Dengan demikian ada 6 atau $20 \%$ siswa yang meningkat disiplinnya dari sedang menjati tinggi, dan ada 7 atau $23,33 \%$ siswa yang meningkat disiplinnya dari rendah 
menjadi sedang. Hasil identifikasi menunjukkan bahwa disiplin rendah terjadi pada cara berpakaian, perilaku menyontek saat ulangan dan dalam mengerjakan tugas dari guru, serta membuang sampah sembarang tempat. Kondisi ini terjadi terjadi karena cenderung cara berpakaian di sekolah tidak dianggap sebagai hal yang patal dan bukan pelanggaran berat. Begitu juga perilaku menyotek tidak lagi dianggap hal yang patal sehingga terkadang guru tidak memperdulikan pada siswa yang menyontek. Demikian pula masalah pelanggaran dalam mengerjakan tugas, layaknya dianggap biasa saja sehingga siswa juga sudah menggap hal yang biasa saja dan hampir tidak lagi dipermasalahkan di sekolah. Selanjutnya disiplin siswa yang rendah adalah membuang sampah bukan pada tempatnya, juga dinilai bukan masalah yang patal apalagi hanya dengan sampah kertas atau potong ketras atau pembungkus makanan ringan. Siswa yang memiliki perilaku rendah ini umumnya mereka adalah dari keluarga sederhana dengan pekerjaan orang tua (ayah) adalah kebanyakan wirausahawan dan beberapa lagi bekerja sebagai sopir, PNS, kerja bangunan, bengkel dan sebagainya. Kedatangan ke sekolah umumnya mereka diantar oleh orang tua atau anggota keluarga lainnya.

Hasil penelitian ketiga memperlihatkan bahwa perilaku disiplin siswa sebelum memanfaatkan media Leaflet dalam layanan informasi dampak pelanggaran disiplin, ternyata ada 19 siswa yang memiliki perilaku disiplin sedang dan 11 siswa yang memiliki perilaku disiplin rendah. Jumlah tersebut menggambarkan bahwa umumnya siswa ini memiliki perilaku disiplin yang sedang. Setelah diberikan memanfaatkan media Leaflet layanan informasi dampak pelanggaran disiplin, terjadi perubahan pada disiplin siswa, yaitu ada 4 siswa yang memiliki perilaku disiplin tinggi, ada 24 siswa yang memiliki perilaku disiplin sedang dan 2 siswa yang memiliki perilaku disiplin rendah. Jumlah tersebut menggambarkan bahwa umumnya siswa ini memiliki perilaku disiplin yang sedang. Dengan demikian ada 4 atau 13,33 \% siswa yang meningkat disiplinnya dari sedang menjati tinggi, dan ada 9 atau 30\% siswa yang meningkat disiplinnya dari rendah menjadi sedang. Hasil identifikasi menunjukkan bahwa disiplin rendah terjadi pada cara berpakaian, perilaku menyontek saat ulangan dan dalam mengerjakan tugas dari guru, serta membuang sampah sembarang tempat. Kondisi ini terjadi karena cenderung cara berpakaian di sekolah tidak dianggap sebagai hal yang patal dan bukan pelanggaran berat. Begitu juga perilaku menyotek tidak lagi dianggap hal yang patal sehingga terkadang guru tidak memperdulikan pada siswa yang menyontek. Demikian pula masalah pelanggaran dalam mengerjakan tugas, layaknya dianggap biasa saja sehingga siswa juga sudah menggap hal yang biasa saja dan hampir tidak lagi dipermasalahkan di sekolah. Selanjutnya disiplin siswa yang rendah adalah membuang sampah bukan pada tempatnya, juga dinilai bukan masalah yang patal apalagi hanya dengan sampah ketras atau potong ketras atau pembungkus makanan ringan. Siswa yang memiliki perilaku rendah ini umumnya mereka adalah dari keluarga sederhana dengan pekerjaan orang tua (ayah) adalah kebanyakan wirausahawan dan beberapa lagi bekerja sebagai sopir, PNS, kerja bangunan, bengkel dan sebagainya. Kedatangan ke sekolah umumnya mereka diantar oleh orang tua atau anggota keluarga lainnya.

Hasil analisis uji hipotesis menunjukkan bahwa ada pengaruh positif pemanfaatan media Spanduk dalam layanan informasi dampak pelanggaran disiplin terhadap peningkatan disiplin siswa. Hal ini ditandai dengan adanya peningkatan rata-rata perilaku disiplin siswa dari 177,6 (sebelum layanan) menjadi 185,73 (sesudah layanan) 
dengan selisih 18,3 dan t-hitung sebesar 5,42 dengan taraf sigifikansi 0,001. Hasil penelitian ini sesuai dengan hasil penelitian Kurniawan, W. (2016) bahwa "penggunaan spanduk yang ukuran dan dominasi pada spanduk tertib lalu lintas terlihat efektif menginformasikan masyarakat Kecamatan Sambutan Kota Samarinda tentang keselamatan berkendara". Hasil identifikasi peningkatan disiplin terjadi pada aspek ketepatan datang kesekolah, mengikuti pelajaran di kelas, ketepatan waktu masuk kelas, mengerjakan tugas, mengikuti upacara hari Senin, memelihara fasilitas sekolah. Sedangkan ada beberapa aspek disiplin yang tidak mengalami peningkatan yang berarti yaitu kedisiplinan dan berpakaian, perilaku menyontek, membuang sampah disembarang tempat, dan tidak merokok dilingkungan sekolah. Peningkatan disiplin siswa pada sejumlah aspek tersebut dapat dipahami bahwa aspek tersebut memang lebih mudah untuk diperbaiki, sedangkan yang lainnya agak sulit untuk diperbaiki karena layaknya sudah menjadi kebiasaan bagi siswa dan cenderung kurang diperhatikan oleh guru-guru di sekolah.

Hasil analisis inferensial memberikan gambaran yang jelas mengenai pengembangan perilaku disiplin siswa di sekolah sesudah memanfaatkan media $X$ Banner dalam pemberian layanan informasi dampak pelanggaran disiplin. Hal ini dapat dilihat dari hasil perhitungan rata-rata skor perilaku disiplin siswa sebelum memanfaatkan media X-Banner dalam pemberian layanan informasi dampak pelanggaran disiplin yaitu 181,9 sedangkan sesudah memanfaatkan media X-Banner ratarata skor perilaku disiplin siswa berubah menjadi 195,3. Berarti selisih rata-rata siswa sebelum dan sesudah memanfaatkan media X-Banner dalam layanan informasi dampak pelanggaran disiplin yaitu 13,4.

Pengembangan perilaku disiplin siswa antara lain ialah siswa datang ke sekolah tepat waktu, siswa mengikuti semua mata pelajaran, siswa berpakaian lengkap, siswa tidak menyontek, siswa tepat waktu datang ke kelas, siswa mengerjakan semua tugas mata pelajaran, siswa mengikuti apel, siswa menjaga fasilitas sekolah, siswa membuang sampah pada tempatnya dan siswa tidak merokok.

Uraian di atas menunjukkan bahwa perilaku disiplin siswa mengalami perkembangan sesudah memanfaatkan media $X$-Banner dalam layanan informasi dampak pelanggaran disiplin, karena sebelum memanfaatkan media X-Banner dalam layanan informasi dampak pelanggaran disiplin, sebagian siswa kurang memiliki pengetahuan dan pemahaman yang baik mengenai dampak dari pelanggaran disiplin. Menurut Prayitno dan Amti, E. (2011) yang menyatakan bahwa "kekurangan pahaman, sering membuat siswa kehilangan kesempatan dan salah arah. Untuk menghindari kejadiankejadian yang dapat merugikan itu mereka perlu dibekali dengan informasi yang cukup dan akurat".

Pengembangan perilaku disiplin siswa terjadi karena isi media X-Banner dinilai sesuai dengan keadaan siswa dan menempatkannya di depan kelas, baik saat maupun sesudah pemberian materi layanan informasi tentang dampak pelanggaran disiplin dengan memanfaatkan media, sehingga dapat disimpulkan bahwa salah satu cara yang dapat dilakukan untuk meningkatkan perilaku disiplin siswa adalah dengan pemberian layanan informasi dampak pelanggaran disiplin dengan memanfaatkan media X-Banner. Hal ini dapat dilihat dari perubahan yang terjadi pada permasalahan perilaku disiplin 
siswa yang kurang baik dapat ditangani dan diselesaikan dengan memanfaatkan media $X$-Banner dalam pemberian layanan informasi kepada siswa. Berdasarkan hasil penelitian ini, dapat dibuktikan bahwa pemanfaatan media X-Banner dalam pemberian layanan informasi dampak pelanggaran disiplin dapat mengembangkan perilaku disiplin. Selain itu, pemanfaatan media X-Banner dalam pemberian layanan informasi dampak pelanggaran disiplin efektif digunakan untuk mengembangkan perilaku disiplin siswa di sekolah, karena media ini di desain secara menarik, isi informasi yang disampaikan juga di desain secara singkat dan jelas sehingga siswa tertarik untuk membaca serta mudah memahami dampak dari pelanggaran disiplin.

Hasil penelitian menunjukkan bahwa perilaku disiplin siswa sebelum memanfaatkan media Leafleat dalam layanan informasi dampak pelanggaran disiplin dengan dari 30 orang siswa yang menjadi subjek penelitian, ada 19 atau 63,33\% siswa yang memiliki perilaku disiplin sedang, 11 atau $36,67 \%$ siswa yang memiliki perilaku disiplin rendah. Hal ini menunjukkan bahwa perilaku disiplin siswa tergolong sedang dan rendah. Misalnya masih ada siswa yang sering melakukan pelanggaran meskipun sudah mengetahui dampak dari pelanggaran disiplin. Pemanfaatan media Leafleat dalam layanan informasi dampak pelanggaran disiplin, dapat memberikan pemahaman kepada siswa mengenai aturan-aturan yang harus ditaati atau dipatuhi dan siswa mampu menghndari dampak dari pelanggaran disiplin.

Hasil analisis deskriptif perilaku disiplin siswa sesudah memanfaatkan media Leafleat dalam layanan informasi dampak pelanggaran disiplin dengan mengalami perkembangan. Sebelumnya tidak ada atau $0 \%$ siswa yang memiliki perilaku disiplin tinggi, namun sesudah memanfaatkan media Leafleat dalam layanan layanan informasi dampak pelanggaran disiplin, ternyata ada 4 atau 13,33\% siswa yang memiliki perilaku disiplin tinggi. Siswa yang memiliki perilaku disiplin sedang yang sebelumnya ada 19 atau $63,33 \%$ setelah memanfaatkan media Leafleat dalam layanan informasi dampak pelanggaran disiplin, mengalami peningkatan sebanyak 24 atau $80 \%$, siswa yang masih memiliki perilaku disiplin rendah yang sebelumnya ada 11 atau 36,67\%. Hasil identifikasi menunjukkan bahwa disiplin rendah terjadi pada cara berpakaian, perilaku menyontek saat ulangan dan dalam mengerjakan tugas dari guru, serta membuang sampah sembarang tempat. Kondisi ini terjadi terjadi karena cenderung cara berpakaian di sekolah tidak dianggap sebagai hal yang patal dan bukan pelanggaran berat. Begitu juga perilaku menyotek tidak lagi dianggap hal yang patal sehingga terkadang guru tidak memperdulikan pada siswa yang menyontek. Demikian pula masalah pelanggaran dalam mengerjakan tugas, layaknya dianggap biasa saja sehingga siswa juga sudah menggap hal yang biasa saja dan hamper tidak lagi dipermasalahkan di sekolah. Selanjutnya disiplin siswa yang rendah adalah membuang sampah bukan pada tempatnya, juga dinilai bukan masalah yang patal apalagi hanya dengan sampah ketras atau potong ketras atau pembungkus makanan ringan. Siswa yang memiliki perilaku rendah ini umumnya mereka adalah dari keluarga sederhana dengan pekerjaan orang tua (ayah) adalah kebanyakan wirausahawan dan beberapa lagi bekerja sebagai sopir, PNS, kerja bangunan, bengkel dan sebagainya. Kedatangan ke sekolah umumnya mereka diantar oleh orang tua atau anggota kelurga lainnya.

Peningkatan perilaku disiplin siswa sebelum dan sesudah memanfaatkan media Leafleat dalam layanan informasi dampak pelanggaran disiplin adalah 43,33\%. 
Peningkatan tersebut terjadi karena materi Leafleat dalam layanan informasi dampak pelanggaran disiplin dengan sangatlah tepat. Pada pertemuan pertama, diberikan materi tentang dampak pelanggaran disiplin antara lain datang lambat kesekolah, membolos, dan tidak berpakaian rapi. Kemudian pada pertemuan kedua, diberikan materi tentang dampak pelanggaran disiplin antara lain: lambat masuk kelas, menyontek, tidak mengikuti apel dan tidak mengerjakan tugas. Selanjutnya pada pertemuan ketiga, diberikan materi tentang dampak pelanggaran disiplin antara lain: membuang sampah bukan ditempatnya, merusak fasilitas sekolah, dan merokok. Media Leafleat dalam layanan infomasi ini didesain secara singkat dan didalamnya tercantum jenis-jenis pelanggaran serta dampak pelanggaran disiplin, hal inilah yang juga membuat siswa tertarik dan mudah memahami isi informasi yang disampaikan peneliti. Namun peningkatan perilaku disiplin siswa masih tergolong rendah. Hal itu disebabkan karena saat pemberian layanan masih ada beberapa siswa yang tidak terlalu memperhatikan penjelasan tentang materi yang disampaikan dimana beberapa siswa tersebut hanya bermain dengan temannya dan bahkan ada yang keluar masuk kelas saat pemberian layanan berlangsung.

Hasil analisis inferensial memberikan gambaran yang jelas mengenai peningkatan perilaku disiplin siswa di sekolah sesudah memanfaatkan media Leafleat dalam layanan informasi dampak pelanggaran disiplin. Hal ini dapat dilihat dari hasil perhitungan ratarata skor perilaku disiplin siswa sebelum diberikan layanan informasi dampak pelanggaran disiplin dengan memanfaatkan media Leafleat yaitu 185,87. Sesudah diberikan layanan informasi dampak pelanggaran disiplin dengan memanfaatkan media Leafleat rata-rata skor perilaku disiplin siswa berubah menjadi 201,4. Selisih rata-rata siswa sebelum dan sesudah diberikan layanan informasi dampak pelanggaran disiplin dengan memanfaatkan media Leafleat yaitu 15,53.

Peningkatan perilaku disiplin siswa antara lain ialah siswa akan datang ke sekolah tepat waktu, siswa akan mengikuti semua mata pelajaran, siswa berpakaian lengkap, siswa tidak akan menyontek, siswa akan tepat waktu datang ke kelas, siswa akan mengerjakan semua tugas mata pelajaran, siswa akan mengikuti apel, siswa akan menjaga fasilitas sekolah, siswa akan membuang sampah pada tempatnya dan siswa tidak akan merokok.

\section{SIMPULAN}

Setelah memanfaatkan media Spanduk dalam layanan informasi dampak pelanggaran disiplin, ternyata : 1 ) ada $40 \%$ siswa yang meningkat disiplinnya dari rendah menjadi sedang, 2) memanfaatkan media X-Banner, ternyata ada $20 \%$ siswa yang meningkat disiplinnya dari sedang menjadi tinggi, dan 23,33\% siswa yang meningkat disiplinnya dari rendah menjadi sedang, 3) memanfaatkan media Leafleat, ternyata ada $13,33 \%$ siswa yang meningkat disiplinnya dari sedang menjadi tinggi, dan $30 \%$ siswa yang meningkat disiplinhya dari rendah menjadi sedang.

Terdapat pengaruh pemanfaatan media Spanduk dalam layanan informasi dampak pelanggaran disiplin terhadap disiplin siswa di sekolah. Selanjutnya, ada pengaruh pemanfaatan media $X$ - Banner dalam layanan informasi dampak pelanggaran disiplin 
terhadap disiplin siswa di sekolah. Terakhir, ada pengaruh pemanfaatan media Leafleat dalam layanan informasi dampak pelanggaran disiplin terhadap disiplin siswa di sekolah.

\section{REFERENSI}

Amrullah, A. F. (2013). Pengaruh kualitas produk dan promosi terhadap volume penjualan makanan mie instan. tahun ajaran2012/2013 (Skripsi tidak diterbitkan). Semarang: Universitas Negeri Semarang.

Fiana, F. J., Daharnis, D., \& Ridha, M. (2013). Disiplin siswa di sekolah dan implikasinya dalam pelayanan bimbingan dan konseling. Konselor, 2(3), 26-33.

Kurniawan, W. (2016). Efektivitas spanduk tertib lalu lintas dalam meningkatkan pengetahuan tentang keselamatan berkendara pada masyarakat kecamatan sambutan kota Samarinda. Ejournal Ilmu komunikasi, 4(2), 200-211.

Muakhir. (2012). Pembuatan poster, leaflet dan booklet (Makalah). Jawa Tengah: Akademi Perawat.

Mulyana, D. (2009). Ilmu komunikasi. Bandung: Citra Aditya Bakti

Nursalim, M. (2015). Pengembangan media bimbingan dan konseling. Jakarta: Indeks.

Prayitno, \& Amti, E. (2011). Dasar-dasar bimbingan dan konseling. Jakarta: Rineka Cipta.

Rimm, S. B. (2003). Mendidik dan menerapkan disiplin pada anak prasekolah: pola asuh anak masa kini. Jakarta: Gramedia Pustaka Utama.

Shimp, A. T. (2003). Periklanan dan promosi. Jakarta: Erlangga.

Siswanto. (2003). Manajemen tenaga kerja indonesia pendekatan administratif dan operasional. Jakarta: Bumi Aksara.

Sofah, R., \& Sucipto, S. D. (2016). Media bimbingan dan konseling. Palembang: Noer Fikri.

Sukardi, D. K., \& Kusmawati, D. P. E. N. (2008). Proses bimbingan dan konseling di sekolah. Jakarta: Rineka Cipta.

Winkel, W. S., \& Hastuti, W. S. (2015). Bimbingan dan konseling di ınstitusi pendidikan. Yogyakarta: Media Abdi.

Zaman, B., et al. (2009). Media dan sumber belajar. Jakarta: Universitas Terbuka. 